\title{
MECHANICAL TRANSMISSION AND SURVIVAL OF BACTERIAL WILT ON ENSET
}

\author{
G. WELDE-MICHAEL, K. BOBOSHA ${ }^{1}$, T. ADDIS, G. BLOMME², S. MEKONNEN \\ and T. MENGESHA \\ Southern Agricultural Research Institute (SARI), Awassa Research Centre, P.O. Box 06, Awassa, Ethiopia \\ ${ }^{1}$ Armauer Hansen Research Institute, P.O. Box. 1005, Addis Ababa, Ethiopia \\ ${ }^{2}$ Bioversity Uganda, P. O. Box 24384, Kampala, Uganda
}

\begin{abstract}
The transmission of enset bacterial wilt with contaminated knives and the survival of the causal agent in soil and enset plant debris was studied at the Awassa Agricultural Research Center, Awassa, Ethiopia. Contaminated knives were found to transmit the pathogen from infected to healthy plants. Disease symptoms were recorded within 15 and 21 days after inoculation on plants inoculated at 6 and 12 months after transplanting, respectively. Enset plants inoculated at 24 and 36 months after transplanting showed initial wilt symptoms 30 days after inoculation. Xanthomonas campestris pv. musacearum $(X \mathrm{~cm})$ isolates were observed to survive in the soil up to 9 days. Thereafter the bacteria population reduced to a level that could not initiate infection. Xcm was also observed to survive in pruned leaf petioles and leaf sheaths for at least 3 months.
\end{abstract}

Key Words: Bacterial wilt, enset, survival, transmission, Xanthomonas campestris pv. musacearum

\section{RÉSUMÉ}

La transmission d'enset bactérien flanche avec les couteaux contaminés et la survie de l'agent causal dans le sol et de débris de plante d'enset a été études à l'Awassa le Centre de Recherche Agricole, Awassa, Ethiopie. Les couteaux infectés été trouvésdangereux pour transmettre le pathogène de plantes infectés aux plantes saines. Les symptômes de maladie ont été enregistrés dans 15 à 21 jours après l'inoculation sur les plantes vaccinées à 6 et 12 mois après avoir transplanté. Plante d'Enset vacciné à 24 et 36 mois après avoir transplanté amontré les symptômes initiaux 30 jours après l'inoculation. Xanthomonas campestris pv. musacearum $(X \mathrm{~cm})$ isolé ont été observé vivant dans le sol jusqu’à 9 jours. Par la suite la population de bactéries a réduit à un niveau qui ne pourrait pas causer l'infection. Xcm a été aussi observé pour vivant dans les petioles de feuille élagué et les gaines de feuille pour au moins 3 mois.

Mots Clés: Bactérien flancher, enset, la survie, la transmission, Xanthomonas campestris pv. musacearum

\section{INTRODUCTION}

Xanthomonas wilt of bananas and Enset (Ensete ventricosum) first reported in Ethiopia in 1968, is the most important disease of domesticated enset (Yirgou and Bradbury, 1968; Quimio and Tessera, 1996). It is caused by Xanthomonas campestris pv. musacearum $(X \mathrm{~cm})$. The main means of spread of this disease are through contaminated farm tools and infected planting materials. As enset plants are harvested before flower emergence, transmission of the disease does not occur via inflorescences. Initial symptoms of the disease on enset include the presence of bacterial ooze in the leaf petioles and leaf sheaths, and progressive wilting of the leaves (Yirgou and Bradbury, 1968; Ashagari, 1985; Quimio and Tessera, 1996).

Initial studies on the transmission of enset bacterial wilt through contaminated farm tools indicated that transmission efficiency has been invariably greater when bacteria came in contact 
with artificially wounded surfaces or when directly deposited into the parenchymatous tissue of the plant. (Ashagari, 1985). Initial studies have shown that the pathogen can temporarily survive in cut off leaves or in plant debris (Quimio and Tessera, 1996). However, the survival period of the pathogen in Enset plant debris used as surface mulch or when buried in the soil needs further investigation.

The present study builds on these initial studies and focuses on artificial infection of enset plants through contaminated knives, and the survival of the pathogen in soil, in plant debris used as surface mulch and debris buried in the soil.

\section{MATERIALS AND METHODS}

\section{Experiment 1: Can contaminated knifes spread} the disease? This trial was conducted from 1997 to 1999 at the Awassa Agriculture Research Centre, Awassa, Ethiopia. A virulent streptomycin resistant $\mathrm{Xcm}$ isolate was used in this experiment. This strain was isolated and preserved at the Awassa Agricultural Research Center plant pathology laboratory in a Yeast Glucose Chalk Agar medium. The virulent bacterial isolate was streaked aseptically onto the surface of YPSA medium on plates. The plates were kept at 27$28^{\circ} \mathrm{C}$ for 72 hours. A bacterial suspension was obtained from 72 hours old cultures by mixing the bacteria in sterilized distilled water. The cell concentration of $X \mathrm{~cm}$ was adjusted to 1 x $10^{8} \mathrm{cfu} /$ $\mathrm{ml}$ (equivalent to $0.3 \mathrm{OD}$ at $460 \mathrm{~nm}$ ).

Uniform and vigorous one-year-old plantlets of enset (clone 'Banga') were transplanted from pots into barrels filled with a mixture of sand and sun-dried composted manure (3:1 ratio). Plants were watered at a weekly interval and weeded when necessary. A suspension of $\mathrm{Xcm}$ was poured into $200 \mathrm{ml}$ beakers and flame sterilized knives were subsequently immersed in the suspension. Five enset plants were inoculated by cutting the petioles of the two oldest leaves with the contaminated knife, while the two oldest leaves on a control plant were cut with a clean flamesterilized knife. These treatments were carried out for different sets of plants at 6, 12, 24, and 36 months after transplanting. Plants were assessed for disease symptoms at 7, 15, 21, 30, 45, 60, 75, 90 and 120 days after inoculation. The time between the inoculation and the appearance of the first symptoms (i.e. the incubation period) and the time between the inoculation and plant death were recorded for all inoculated plants.

Experiment 2: Survival of $X \mathrm{~cm}$ in the soil. A streptomycin resistant $\mathrm{Xcm}$ isolate collected from Hagere Selam, southern Ethiopia, was used for this study. This strain was able to grow on a Yeast Peptone Sucrose Agar (YPSA) media amended with streptomycin (100 ppm). This media has an inhibitory effect on soil fungi and bacteria but is semi-selective to the $X \mathrm{~cm}$ test strain. This medium was used for monitoring the presence of $X \mathrm{~cm}$ in the soil.

Three different soil types (Utric cambisols, Pellic vertisols and Utric nitosols) were collected from non wilt-infested enset fields in the Kembata Tembaro, Wolyita and Sidama zones. The soil was subsequently air-dried and sieved with a $6 \mathrm{~mm}$ mesh to remove large particles and trash. From each zone, $400 \mathrm{~g}$ of soil was taken and mixed with $100 \mathrm{ml} \mathrm{Xcm}$ suspension with a concentration of $1 \times 10^{8}(0.3 \mathrm{OD}$ at $460 \mathrm{~nm})$. The soil moisture level was maintained at field capacity level (Quimio, 1992). The soil samples were placed in plastic bags and kept at the Awassa Agricultural Research Center in the laboratory. The experiment was laid out as a completely randomized design and replicated three times.

Sampling was done at 3-day intervals during the first month after setting up the experiments, while further sampling continued at 10-days interval during the second month. At each time of assessment, a sample of $10 \mathrm{~g}$ from each soil type was mixed with $90 \mathrm{ml}$ of sterile water in a flask. The mixture was then shaken for 10 minutes at 300 rotations per min using an Edmund Bühler (Swip) shaker. One ml from each mixture was serially diluted to $10^{-10}$. From each dilution, 0.2 $\mathrm{ml}$ of the mixture was aseptically streaked with a glass rod on 2 YPSA plates containing streptomycin. The plates were incubated at 27$28^{\circ} \mathrm{C}$ for 72 hours and observed for the presence of $\mathrm{Xcm}$ colonies. Hypersensitivity tests were conducted on tobacco leaves by injecting bacterial suspensions into the intercellular space of leaves using a $5 \mathrm{ml}$ sterile hypodermic syringe and needle, while pathogenicity tests were carried 
out by injecting bacterial suspensions into leaf petioles of young enset plants.

\section{Experiment 3: Survival of the bacteria in enset}

plant debris. Leaf petioles and leaf sheaths were collected from diseased enset plants (5 to 6 years old) in Sidama zone, Hagere Selam District, Chelbessa Peasant Association in 1997. The leaf sheath and petiole samples were then transported to the laboratory of the Awassa Agricultural Research Center, located in Awassa, Southern Ethiopia. The leaf petioles and leaf sheaths were cut into $30 \mathrm{~cm}$ pieces and split longitudinally. The treatments consisted of: 1) leaf petioles and sheaths used as surface mulch (i.e. kept on top of the soil in clay pots filled with soil), 2) leaf petioles and leaf sheaths buried at $15 \mathrm{~cm}$ depth in clay pots filled with soil and 3) leaf petioles and leaf sheaths kept in the laboratory on an isolated bench at ambient temperature $\left(21-25^{\circ} \mathrm{C}\right)$. The experimental setup was a completely randomized design with 24 samples per treatment and 3 replications. In each of the leaf sheaths and petioles 6 sterilized insect pins were inserted to indicate pockets of bacterial ooze in order to make subsequent sampling easier. The clay pots were watered at three-day intervals using a hand sprayer.

In order to monitor the survival of the bacteria, the inner part of the leaf sheaths and petioles was removed using a flame sterilized blade. The infected tissue was taken at 1, 2, 3, 4, 8, 12 and 24 months interval after the installation of the experiment and suspended in sterile water. The bacterial suspension was streaked on a YPSA plate and incubated at $27-28^{\circ} \mathrm{C}$ for 72 hours. The growth of the bacterium on the YPSA plates was monitored and colonies were isolated and subcultured on YPSA plates. The colonies were taken, and a suspension was made and adjusted to 0.3 O.D. ( $\left.1 \mathrm{X} 10^{8} \mathrm{CFU} / \mathrm{ml}\right)$. This suspension was injected into tobacco leaves (hypersensitivity test) and enset leaf petioles (pathogenicity test) to confirm that the bacteria were indeed Xanthomonas campestris pv. musacearum $(\mathrm{Xcm})$. The control in the pathogenicity tests consisted of injecting sterile water into the enset leaf petioles.

\section{RESULTS AND DISCUSSION}

\section{Experiment 1: Can contaminated knifes spread}

the disease? The results of the inoculations with $\mathrm{Xcm}$ contaminated knives are presented in Table 1. It was observed that the younger enset plants were more vulnerable to infection from a contaminated knife. The first $\mathrm{Xcm}$ symptoms (i.e. yellowing at the edge of the leaf) were recorded at 15 and 21 days after inoculation in enset plants which were inoculated at 6 and 12 months after transplanting respectively (Table 1 ). However, enset plants, which were inoculated at 24 and 36 months after transplanting showed initial wilt symptoms at 30 days after inoculation. This suggests that the age of an enset plant influences the susceptibility of the plant to a $\mathrm{Xcm}$ infection with older plants being less vulnerable to infection than young plants.

A 100\% disease incidence was recorded at 60 days after inoculation on plants inoculated at 6 months after transplanting. Plants inoculated at 6 months after transplanting had a $20 \%$ plant death rate (i.e. dried leaves and pseudostem) at 60 days after inoculation. A 100\% disease incidence was observed for all plants at 90 days after inoculation (Table 1). At 150 days after inoculation $100 \%, 80 \%, 60 \%$ and $40 \%$ of the plants inoculated at respectively $6,12,24$ and 36 months after transplanting had died (Table 1). Ashagari (1985) indicated that hundred percent disease transmission was obtained when the bacterial suspension was directly injected into leaf petioles or when petioles were cut with contaminated knives. In a similar study made on the transmission of banana wilt, it was reported that the disease is readily transmitted from plant to plant with knives and machetes used in pruning operations (Seqeira, 1958).

Therefore, this study further confirmed that farm tools (i.e. knives, machetes, spades or hoes) need to be disinfected after being used to destroy a diseased enset plant. The tools could be disinfected with a chemical disinfectant or by putting the tool in fire until the metal glows. In order to create awareness among farmers about the transmission of the disease through contaminated farm tools, sensitization campaigns 
and training of extension agents and farmers is recommended.

Experiment 2: Survival of $X \mathbf{c m}$ in the soil. The results from the study on the survival of $X \mathrm{~cm}$ in the soil are presented in Table 2. Xcm colonies were recovered on the YPSA medium containing streptomycin up to 12 days after the establishment of the experiment for all soil types (Table 2). The number and size of $\mathrm{Xcm}$ colonies recovered on the plates however sharply decreased at 9 days after the start of the trial. The $\mathrm{Xcm}$ isolates obtained on the plates for samples collected at 3 and 6 days induced a positive hypersensitive and pathogenic reaction when inoculated in tobacco leaves and in enset leaf petioles respectively. However, $\mathrm{Xcm}$ isolates recovered at 9 and 12 days did not induce wilt symptom on tobacco leaves or enset suckers (Table 2). This suggests that Xcm cannot survive in the soil for more than 9 days. Ashagari (1985) reported that the survival of $\mathrm{Xcm}$ on contaminated knives does not exceed three days when the knives were incubated in a humid environment and four days when incubated under dry conditions.

The hypersensitive (necrotic and dried) lesion at the point of injection in tobacco leaves was observed within 24 hours after inoculation, while inoculated enset leaf petioles showed disease symptom typical of enset wilt 21 to 30 days after inoculation.

The results showed that $X \mathrm{~cm}$ isolates can survive in the soil up to 9 days. By day 9 the bacterial population is reduced to a level that cannot initiate infection. It is therefore recommended that farmers should allow the infected plots to fallow for at least one cropping season after removing the diseased plants.

\section{Experiment 3: Survival of the bacteria in enset} plant debris. $\mathrm{Xcm}$ colonies were recovered on YPSA medium from samples kept in the laboratory up to 3 months after the onset of the trial (Table $3)$. However, colonies were only recovered up to 2 months after the start of the trial for samples used as surface mulch and up to one month for the samples buried $15 \mathrm{~cm}$ deep in the soil. The number of recovered $\mathrm{Xcm}$ colonies on the YPSA plates strongly decreased with an increase in time 
Transmission and survival of bacterial wilt on enset

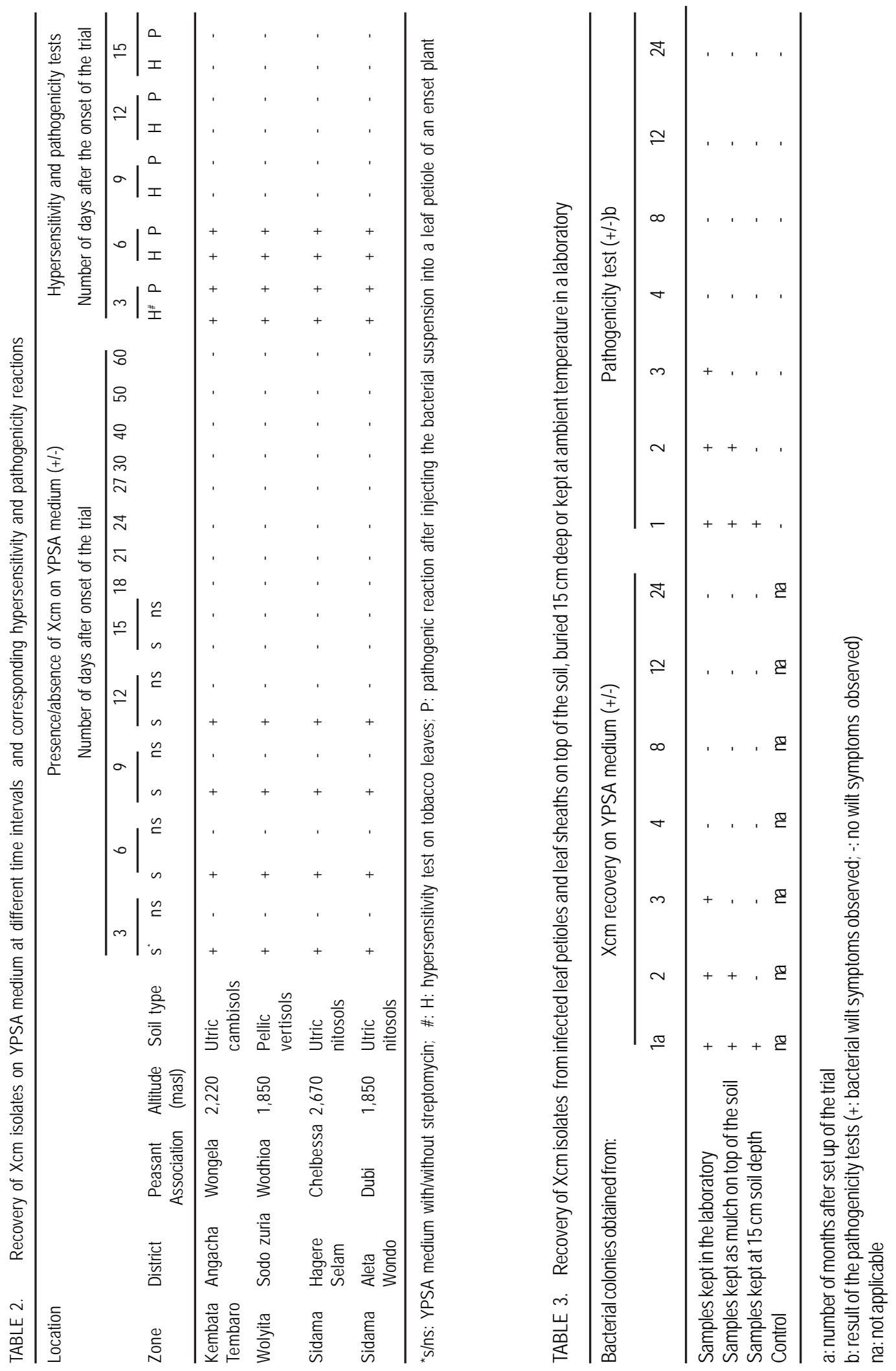


after the installation of the trials. The hypersensitivity and pathogenicity tests confirmed results obtained on the media (Table 3). All control plants in the pathogenicity tests showed a negative reaction. Yirgou and Bradbury (1968) suggested that infected enset plant debris could be a possible source of inoculum for disease transmission.

This study revealed that $X c m$ could survive in leaf petioles and leaf sheaths for up to 3 months. It is hence advised that farmers remove infected enset plants from a field and heap/burry and compost them. The plots should also be allowed to fallow for more than 3 months (at least one cropping season). In addition, plant tissue from infected enset plants should not be used or transported to other locations, as they are a likely source of bacteria.

\section{ACKNOWLEDGEMENTS}

Financial support from the Ethiopian Institute of Agricultural Research (EIAR) and the Southern Agricultural Research Institute (SARI) is gratefully acknowledged. A special thanks also goes to Mr. Frank Turyagyenda for editing the paper.

\section{REFERENCES}

Ashagari, D. 1985. Studies on the bacterial wilt of Enset (Enset ventricosum) and prospects for its control. Ethiopian Journal of Agricultural Science 7(1):1-14.

Quimio, A. J. 1992. Annual report of the plant Pathologist: July 17, 1991-July 16, 1992. Enset Team Support Project. Sidamo, Gamo-Goffa Peasant Agricultural Development Program. PADEP III. Awassa Research Center, IAR.

Quimio, A. J. and Tessera, M. T. 1996. Diseases of enset. In: Tsedeke, A., Hiebsch, C., Brandt, S.A., Seifu, G..M. (Eds), pp. 188-203. EnsetBased Sustainable Agriculture in Ethiopia. In: Proceedings of the International Work shop on enset. Addis Ababa, Ethiopia, 13-20 December 1993.

Seqeira, L. 1958. Bacterial wilt of Banana: Dissemination of the pathogen and control of disease. Phytopathology 48:64-69

Yirgou, D. and Bradbury, J.F. 1968. Bacterial wilt of Enset (Enset ventricosum) incited by Xanthomonas musacearum sp.n. Phytopathology 58:111 - 112. 